\title{
The relationship between EFL Teachers' Attitudes towards CLT and Perceived Difficulties of Implementing CLT in Language Classes
}

\author{
Mehrak Rahimi (Corresponding author) \\ Shahid Rajaee Teacher Training University, Lavizan, Tehran, 1678815811, Iran \\ E-mail: mehrakrahimi@yahoo.com \\ Farhad Naderi \\ Shahid Rajaee Teacher Training University, Lavizan, Tehran, 1678815811, Iran \\ E-mail: naderi1366@yahoo.com
}

Received: 18-01-2013

Accepted: 18-02-2014

Published: 01-05-2014

doi:10.7575/aiac.ijalel.v.3n.3p.237

URL: http://dx.doi.org/10.7575/aiac.ijalel.v.3n.3p.237

\begin{abstract}
The present study investigated the relationship between EFL teachers' attitudes towards CLT and perceived difficulties of implementing CLT in language classes. Two hundred and three EFL teachers participated in the study. Their attitudes towards CLT and their perceptions of the problems of implementing CLT were assessed by two questionnaires. The results of the descriptive statistics showed that EFL teachers had positive attitudes towards CLT in general and group work in communicative classes in particular. Further, while EFL teachers generally did not find much difficulty in implementing CLT in language classes, they found the difficulties the educational system creates as a major obstacle to use CLT. Moreover, CLT attitudes and perceived difficulties of CLT implementation were not found to be related; however, when subscales of CLT attitudes and perceived difficulties questionnaires were considered, three correlations were found to be statistically significant. Difficulties caused by students in communicative classes were found to be inversely and significantly related to (a) attitudes to CLT as a whole $(\mathrm{r}=-.160, p<.05)$ and (b) attitudes towards group/pair work in CLT $(\mathrm{r}=-.156, p<.05)$. Further, attitudes towards the role of teacher in a communicative class were found to be positively related to difficulties inherent in the CLT method itself $(\mathrm{r}=.181, p<.01)$.
\end{abstract}

Keywords: attitudes, CLT, difficulties, problems, teachers

\section{Introduction}

Research on teaching effectiveness shows that attitude is a part of teachers' identity that helps to adopt appropriate teaching strategies and effective instructional behavior (Korthagen, 2004). Teachers' attitudes are a potent determinant of their teaching style (Karavas-Doukas, 1996) and play a significant role in teachers' decision to implement or avoid certain teaching methods and techniques.

Teachers' attitudes are also an indispensable part of curriculum reforms and thus "any innovation in classroom practice from the adoption of a new technique or textbook to the implementation of a new curriculum has to be accommodated within the teacher's own framework of teaching principles" (Breen et al., 2001, p. 472). When educational innovation is incompatible with teachers' attitudes, it is very probable that teachers do not welcome the new educational reform in their classes (Orafi \& Borg, 2009), as they do not perceive it as a valuable teaching resource and they may even resist such change. Thus, it is crucial to determine teachers' attitudes towards that innovation and then "revise, refine, or change attitudes which may not be compatible with the principles of that approach" (Karavas-Doukas, 1996, p. 188).

It is suggested that one reason of the mismatch between the theory of certain methods, such as communicative language teaching (CLT), and their actual practice is rooted in teachers' attitudes (Karavas-Doukas, 1995; Carless, 2003). The context in which CLT is used determines its success or failure (Philipson, 1992) as good teaching practices are socially intertwined with a particular cultural environment (Ozsevik, 2010). As a learner-centered approach to teaching language whose goal is communication rather than mastery of language forms, CLT may cause more negative attitudes among teachers in the EFL context where grammar instruction plays a key role in the language curriculum due to the washback effect nationwide exams have on teaching. Also, many EFL teachers believe that overemphasizing the oral skills at the cost of the written skills is not a realistic goal of teaching and learning English as a foreign language (Carless, 2007).

Besides, negative attitudes of teachers towards CLT can be attributed to the fact that CLT is rooted in an Anglo-Saxon view of education (Hiep, 2007) and thus cannot be suitable to be used in other parts of the world if it does not undergo certain modifications (Carless, 2003). The way "teachers interpret, filter, modify, and implement curricula will be influenced by contextual factors in and around their workplaces" (Orafi \& Borg, 2009, p. 244). If the incongruity between the educational innovation and the understandings of teachers of their role, their students' needs, and what the 
educational system demands is widen, several problems such as negative attitudes, additional workload, and resistance to change will be created when the innovation is implemented in the classroom (Carless, 2013).

Classroom-based research shows that teachers encounter difficulties in actual implementation of communicative approach due to internal and external constraints (e.g., Anderson, 1993; Hui, 1997; Surafel, 2002). Internal constraints are mainly those that are related to teachers themselves such as lacking a professional knowledge base (e.g., declarative or procedural knowledge). External constraints, on the other hand, are the ones that teachers cannot control. These constraints are related to the educational system such as lack of resources, time constraints, and populated classes.

Although the role of teachers' attitudes in adopting teaching approaches has widely cared for in the literature, there is a dearth of research on the role of teachers' attitudes towards communicative approach in their perceptions of practical problems of implementing such an approach in language classes. Investigating teachers' attitudes "serves as a starting point to identify the possible contradictions between teachers' beliefs and CLT principles" (Chang, 2010, p. 18); and the reasons why teachers have problems in implementing CLT in their classes. Therefore, the present study investigates the relationship between teachers' attitudes towards CLT and practical problems of implementing CLT methodology in language classes of an EFL setting, Iran.

\subsection{Research questions}

The study seeks answers to the following research questions:

1. What are EFL teachers' attitudes towards CLT?

2. What are the major problems of implementing CLT in language classes as perceived by EFL teachers?

3. Is there any relationship between CLT attitudes and difficulties of implementing CLT in language classes as perceived by EFL teachers?

\subsection{Communicative Approach}

Historically, language-teaching methodology has been swinging like a pendulum between polar extremes as educationists have searched for practical solutions of the problems language teachers face in their classes (Rathore, 2012). Language teaching methodology has vacillated between such polar opposites as oral vs. written skills; fluency vs. accuracy; competence vs. performance; meaning vs. form; product vs. process; and analogy vs. analysis. The swing of pendulum is observable in the shifts from methods that overemphasized teaching written skills (Grammar-Translation Method, Reading Approach) to oral skills (Direct Method, Audio Lingual Method) or those that focused on form (Phonics) to meaning (the Whole Language) (Chen, 1995). Communicative Language Teaching (CLT) has emerged as a result of pendulum swing from methods that focused on forms and usage of language (Savignon, 1991), that could not fulfill language learners' communicative needs, to those that focused on language use and communicative goals of language teaching and learning (Richards \& Rodgers, 1986).

CLT represents a philosophy of teaching based on communicative language use and is defined as "an approach to foreign or second language teaching which emphasizes that the goal of language learning is communicative competence and which seeks to make meaningful communication and language use a focus of all classroom activities" (Richards \& Schmidt, 2002, p. 90). The main focus of CLT is communication rather than accuracy and mastery of language forms and thus the roles it assigns to teachers and learners are fundamentally different from those found in traditional language classes (Richards \& Rogers, 2001). CLT "emphasizes the development of learners' ability to communicate, express themselves, get their meaning across, and engage in social interaction" (Gor \& Vatz, 2009, p. 245). In such a learner-centered classroom, students should feel safe, secure and relaxed; and the teacher should avoid adopting a teacher-centered and authoritarian attitude (Rahimi \& Asadollahi, 2011). The CLT teacher thus is a facilitator, an independent participant, a researcher and needs analyst, a counselor, and group process manager (Richards \& Rodgers, 2001). Table 1 summarizes a five-element framework that Badger and Yan (2008) have proposed to describe CLT.

Table 1. A description of CLT (Taken from Badger \& Yan, 2008, p. 8)

\begin{tabular}{ll}
\hline Pedagogical orientation & Balanced attention to the four language skills \\
\cline { 2 - 2 } Instructional content and presentation & Focus on students' ability to use the L2 \\
\cline { 2 - 2 } & \begin{tabular}{l} 
Use of the L2 in conducting a lesson \\
\cline { 2 - 2 }
\end{tabular} \\
\cline { 2 - 2 } & Teaching of communicative functions \\
\hline Language practice & Use of open-ended questions \\
\hline & Teacher-student interaction in L2 \\
\hline & Games and activities resembling real-world \\
& tasks \\
\hline
\end{tabular}

Constant exposure to new language input 


\begin{tabular}{ll}
\hline & \multicolumn{1}{l}{ Communication in L2 among students } \\
\cline { 2 - 2 } & Integrated practice in the four language skills \\
\cline { 2 - 2 } Teacher and learner role & Reading and writing about various topics \\
\hline Listening and speaking about various topics \\
\hline Materials & Pair and small group work \\
\cline { 2 - 2 } & Peer feedback and evaluation \\
\hline & Teacher-developed materials \\
\hline & Authentic materials \\
\hline Ability to use the L2 \\
\hline
\end{tabular}

\subsection{Teachers' Attitudes}

Attitudes are defined as "the interplay of feelings, beliefs and thoughts about actions" (Rusch \& Perry, 1999, p. 291). Teachers' attitudes are of paramount importance to the process of implementing changes in the educational system. Based on the theory of Diffusion Of Innovation (DOI), the success of a diffusion campaign to implement a new idea or practice in the educational setting depends on the nature of innovation, the targeted adopters and their socioorganizational contexts, as well as the flow of information about the innovation through various communication structures and channels such as mass media and interpersonal networks (Rogers, 2003).

The nature of the change and whether an innovation is idea- or practice-based, can affect the implementation of that innovation; while the idea-based one is more difficult to implement (Carlson, 1968). Besides, adopters' volition, their personality traits and social behaviors are significant factors in the adoption of an innovation. Whether an innovation is of an optional (individual decision), collective (group decision), or mandated type is another dimension that affects the rate of change. In the case of educational innovations, mandated decisions are associated with a lower rate of diffusion and adoption of change (Fullan, 1993). Regarding personality traits of an educator, favorable and positive attitudes towards change are factors that facilitate its adoption (Nation \& McAlister, 2010).

Empirical studies show that EFL teachers in general have positive attitudes towards communicative approach in different countries (e.g., Chang, 2000; Liao, 2003; Razmjoo \& Riazi, 2006; Hawkey, 2006). However, these positive attitudes do not necessarily guarantee teachers' use of CLT in their classes and inconsistency between teachers' beliefs, which agree with CLT principles, and their actual practice, which deviates from CLT principles are observed (e.g., Badger \& Yan, 2008; Orafi \& Borg, 2009).

By contrast, in some studies teachers have shown negative attitudes to CLT (Tsai, 2007) and believe that communicative approach is more useful for students who live in English-speaking context not for EFL learners (Burnaby \& Sun, 1989). Some believe that communicative approach should be modified based on their contextual variables (milieu) if it is going to be used in their language classes (e.g., Carless, 2003; 2007). As "teachers' attitudes and beliefs remain the single strongest guiding influence on instruction" (Gorsuch 2000, p. 678), these negative attitudes can be the source of difficulties teachers face in implementing CLT. Experiencing difficulty in communicative classes may lead to teachers' higher negative attitudes or modification of CLT when it is being implemented. Teachers may even fall back to on their established practice (Savignon \& Wang, 2003).

\subsection{Difficulties of Implementing CLT}

Although CLT has been widely used by many teachers across the globe since its emergence, the appropriacy of CLT in the Asian context is open to debate (e.g., Hiep, 2007; Kumaravadivelu, 2006). The main reason language experts give for this inappropriacy is the problems implementing CLT creates in language classes. Reviewing the literature of the past two decades shows that problems teachers face in using communicative and/or task-based language teaching can be related-but not limited- to the following:

- Institutional factors: such as class size (Burnaby \& Sun, 1989) and the washback effect of grammar-based tests on teaching (Liu, 2005);

- Student-related factors: such as students' lack of motivation to develop their communicative competence (Li, 1998)

- Difficulties inherent in CLT itself: such as lack of effective and efficient assessment instruments (Li, 1998), time-consuming activities (Sato \& Kleinsasser, 1999), and unsuitability of CLT for the local context (Chang, 2010);

- Teacher-related factors: such as lack of knowledge of the Western culture (Ellis, 1994), teachers' disbelief in the value of the practical implications of the CLT principles (Karavas-Doukas, 1996; Coskun, 2011), teachers' fragmented knowledge of CLT (Sato \& Kleinsasser, 1999), teachers' resistance to use the target language (Gorsuch, 2000), and teachers' limited language proficiency (Carless, 2003).

Although these studies have determined the difficulties of implementing CLT in classroom settings, it appears that the role of teachers' attitudes in implementing CLT in language classes is taken for granted in the literature (Mulat, 2003). 


\section{Method}

\subsection{Participants}

The participants of the current study were 203 EFL teachers who worked in public schools of one metropolitan city of Iran in the academic year 2012-2013. Of the sample $80(39.4 \%)$ were male and $123(60.6 \%)$ were female. Their age ranged from 24 to 64 with the mean of $38.65(\mathrm{SD}=7.3)$. The teachers had from 1 to 35 years of teaching experience $($ mean $=15.8, \mathrm{SD}=7.42)$.

\subsection{Instruments}

The two questionnaires that were used in this study were:

- Attitudes towards CLT Questionnaire, and

- Perceived Difficulties of CLT Implementation Questionnaire

\subsubsection{Attitudes towards CLT Questionnaire}

Attitudes towards CLT were measured by Attitudes towards CLT Questionnaire (Karavas-Doukas, 1996). The scale consists of 24 items anchored on a 5-point Likert scale from 1 (strongly disagree) to 5 (strongly agree) (See Appendix 1). The items have been categorized into five subscales including: place and importance of grammar (6 items); role of teacher in classroom (4 items); group/pair work (4 items); role and contribution of learners in learning process (6 items); and quantity of error correction (4 items).

The split-half reliability coefficient of the scale as estimated by the developer has been reported to be 0.88 . The questionnaire has been used with an Iranian sample and the reliability coefficient of .73 has been reported (Rahimi \& Naderi, 2013). The reliability of the scale for the current study was found to be 0.79 using the internal consistency method.

\subsubsection{Perceived Difficulties of CLT Implementation Questionnaire}

The second instrument measured the difficulty of implementing CLT as it was perceived by EFL teachers (Ozsevik, 2010). The scale has 18 items that are anchored on a 4-point Likert scale including $4=$ Major challenge; $3=$ Challenge; $2=$ Mild challenge; and $1=$ Not a challenge at all. CLT difficulties and challenges were assessed under four main factors including teacher-related challenges (6 items), student-related challenges (4 items), educational system-related challenges (5 items), and CLT-related challenges (3 items).

The reliability coefficient of the scale was estimated to be 0.78 in the current study using the internal consistency method.

\section{Results}

In order to answer research questions one and two descriptive statistics were used. Table 2 summarizes 203 EFL teachers' means and standard deviations on Attitudes towards CLT Questionnaire and Perceived Difficulties of CLT Implementation Questionnaire and their subscales. The average score of attitudes questionnaire is 3.71 (while each item was measured by a 5-point Likert scale) indicating that EFL teachers had overall positive attitudes towards CLT. The highest mean is related to 'group/pair work' (mean=4.27) implying that teachers have highly positive attitudes towards implementing group work in language classes. The lowest mean is related to 'quality and quantity of error correction' (mean=3.59) showing that teachers have roughly positive attitudes towards error correction patterns of CLT. What is noteworthy is that teachers did not show any negative attitudes towards CLT as the means of none of the subscales is lower than 3 .

Table 2. Descriptive statistics of the questionnaires and their subscales

\begin{tabular}{lccc}
\hline Scale & $\begin{array}{c}\text { Number of } \\
\text { items }\end{array}$ & Mean & SD \\
\hline Attitudes towards CLT & 24 & 3.707 & .434 \\
Place and importance of grammar & 6 & 3.364 & .552 \\
Role of teacher in classroom & 4 & 3.864 & .594 \\
Group/pair work & 4 & 4.270 & .577 \\
$\quad$ Role/contribution of learners in learning & 6 & 3.645 & .536 \\
process & & & \\
Quality/quantity of error correction & 4 & 3.594 & .748 \\
\hline Perceived difficulties of CLT & 18 & 2.893 & .402 \\
implementation & & & \\
$\quad$ Teacher-related difficulties & 6 & 2.971 & .572 \\
Student-related difficulties & 4 & 2.591 & .745 \\
Educational system difficulties & 5 & 3.170 & .581 \\
CLT-related difficulties & 3 & 2.679 & .621 \\
\hline
\end{tabular}


The average score of difficulties questionnaire is 2.8 (while each item was measured by a 4-point Likert scale) indicating that EFL teachers do not find much difficulty in implementing CLT in their classes in general. The highest mean score is related to difficulties caused by the educational system (mean=3.2), implying that teachers believe that the educational system acts as a barrier in implementing communicative approach in language classes. The means of other factors are not above 3; showing that teachers do not perceive teachers, students, or the communicative approach itself as major obstacles in implementing CLT in their classes.

In order to answer research question three, Pearson Product correlation method was used. The results of the analysis showed that in general, CLT attitudes and perceived difficulties of CLT implementation were not related ( $\mathrm{r}=-.01)$. However, when subscales of the two questionnaires were considered, three correlations were found to be statistically significant (Table 3).

CLT attitudes as a whole were found to be inversely and significantly related to difficulties caused by students in communicative classes $(\mathrm{r}=-.160, p<.05)$. This finding shows that those teachers who have general positive attitudes towards CLT do not consider students as a major obstacle in implementing CLT in language classes.

Further, attitudes towards 'the role of teacher in a communicative class', were found to be positively related to CLTrelated difficulties $(\mathrm{r}=.181, p<.01)$. In other words, those who have favorable attitudes to the role of teachers in the communicative classes believe that the problems of CLT are mainly related to the approach itself.

Also, attitudes towards 'group and pair work in communicative classes' were significantly and inversely related to 'student-related difficulties of CLT' $(\mathrm{r}=-.156, p<.05)$. It means that those teachers who have positive attitudes towards group work in CLT, believe that students cannot be a source of difficulty in implementing communicative approach in language classes.

Table 3. Correlation Matrix of the interrelationship between variables

\begin{tabular}{|c|c|c|c|c|c|c|c|c|c|c|c|}
\hline Variables & 1 & 2 & 3 & 4 & 5 & 6 & 7 & 8 & 9 & 10 & 11 \\
\hline 1 Attitudes towards CLT & 1 & $.75^{* *}$ & $.65^{* *}$ & $.67^{* *}$ & $.77^{* *}$ & $.79^{* *}$ & -.01 & .09 & $-.16^{*}$ & -.01 & .08 \\
\hline 2 Place/importance of grammar & & 1 & $.285^{*}$ & $.443^{* *}$ & $.402^{* *}$ & $.506^{* *}$ & -.046 & .017 & -.105 & -.031 & .004 \\
\hline 3 Role of teacher in classroom & & & 1 & $.315^{* *}$ & $.389^{* *}$ & $.491^{* *}$ & .092 & .098 & -.087 & .086 & $.181^{* *}$ \\
\hline 4 Group/pair work & & & & 1 & $.451^{* *}$ & $.342^{* *}$ & -.023 & .060 & $-.156^{*}$ & .042 & -.017 \\
\hline 5 Role/contribution of learners & & & & & 1 & $.508^{* *}$ & -.010 & .086 & -.130 & -.047 & .084 \\
\hline $\begin{array}{l}6 \text { Quality/quantity of error } \\
\text { correction }\end{array}$ & & & & & & 1 & -.014 & .071 & -.110 & -.040 & .054 \\
\hline 7 Perceived Difficulty & & & & & & & 1 & $.676^{* *}$ & $.600^{* *}$ & $.729^{* *}$ & $.542^{* *}$ \\
\hline 8 Teacher-related difficulties & & & & & & & & 1 & .103 & $.330^{* *}$ & 104 \\
\hline 9 Student-related difficulties & & & & & & & & & 1 & $.199^{* *}$ & $.233^{* *}$ \\
\hline 10 Educational system difficulties & & & & & & & & & & 1 & $.347^{* *}$ \\
\hline 11 CLT-related difficulties & & & & & & & & & & & 1 \\
\hline
\end{tabular}

${ }^{*} p<.05 ; * * p<.01$

\section{Discussion}

The primary goal of this study was investigating the level of Iranian EFL teachers' attitudes towards CLT and the problems they face in implementing this method in their classes. The study also probed into the relationship between EFL teachers' CLT attitudes and its implementation challenges.

Descriptive statistics showed that in line with other studies (e.g., Liao, 2003; Hawkey, 2006) Iranian teachers have general positive attitudes towards CLT. This is a promising finding as the EFL teachers are aware of the values of communicative approach. It was also found that EFL teachers had positive attitudes towards group/pair work in communicative classes. In other words, they know the value of group work and understand that group work creates valuable opportunities for students to interact and experience a more learner-centered and a less teacher-dominant learning atmosphere (Richard \& Rodgers, 2001).

Further, it was found that the only obstacle teachers perceived to face in implementing CLT in language classes is created by the educational system of Iran. They believed that factors such as: lack of enough support from administration, lack of authentic materials, incompatibility of traditional view towards teachers and learners' role with CLT, ineffectiveness of large classes for experiencing CLT, and negative impact of grammar-based examinations on the use of CLT, are the major impediments in using CLT in Iran. This corroborates the findings of other research conducted in the Asian setting (e.g., Chang, 2010) suggesting that "a conflict apparently exists between what CLT demands and what the EFL situation in many countries ....... allows. This conflict must be resolved before EFL teaching in these countries can benefit from CLT" (Li, 1998, p. 696).

The findings also showed that teachers' favorable and positive attitudes towards CLT were not related to difficulties they experienced in their classes in general. This suggests that teachers' attitude is not the only factor to ensure the implementation of innovation and change in the educational system. Other factors such as the nature of that innovation and socio-organizational context of change should be considered (Rogers, 2003; Carless, 2013). 
Teachers' favorable attitudes toward CLT in general were inversely related to difficulties caused by students in communicative classes. This implies that teachers who had general positive attitudes towards CLT had fewer problems with difficulties caused by students such as students' low-level of English proficiency, their passive style of learning, their resistance in participating in communicative class activities, and their lack of motivation for developing communicative competence. In other words, general positive attitudes toward a leaner-centered approach of teaching help teachers manage their classes more successfully (Rahimi \& Asadollahi, 2011) and thus feel less difficulty in using CLT in their classes.

Besides, teachers who had more positive attitudes towards group work activities believed that students are not a major obstacle in the process of implementing CLT. It is evident that activities done in pair and group "maximize students' interaction and ...facilitate students' contribution to each other's learning” (Richards \& Rodgers, 2001, p. 201). Thus, if these types of activities are done appropriately, they decrease difficulties of implementing CLT.

It was also found that teachers who had favorable attitudes towards the role of teachers in communicative classes, believed that the problems of CLT are mainly related to the method itself. In other words, these teachers believed that CLT is not suitable to be used in Asia or an EFL context not because they did not accept the role communicative approach assigned to them, but because the method has certain problems at the level of theory and practice (Badger \& Yan, 2008).

\section{Conclusions}

As the findings of the current study suggest, Iranian EFL teachers have a general positive attitude towards CLT, they know what the group work is and what benefits it offers, and they are aware of both strengths and weaknesses of implementing CLT in the EFL context. The only obstacle teachers face in implementing CLT is related to the educational system of Iran and its top-down curriculum type. Therefore, Iranian mainstream education needs to undergo fundamental changes both at the macro and micro levels in order to guarantee teaching/learning efficiency. As the study shows teachers own enough knowledge of and positive attitudes towards CLT and they are ready to embrace the shift from traditional methods to communicative and learner-centered approaches.

\section{References}

Anderson, J. (1993). Is the communicative approach practical for teaching English in China? Pros and cons. System, 21, 417-480.

Badger, R., \& Yan, X. (2008). To what extent is communicative language teaching a feature of IELTS classes in China? IELTs Research Report Volume 13. IDP: IELTS Australia and British Council. https://www.ielts.org/PDF/vol13_Report4.pdf

Breen, M., Hird, B., Milton, O., \& Thwaite, A. (2001). Making sense of language teaching: Teachers' principles and classroom practices. Applied Linguistics 22,470-501.

Burnaby, B., \& Sun, Y. (1989). Chinese teachers' views of western language teaching: Context informs paradigms. TESOL Quarterly, 23, 219-237.

Carless, D. (2003). Factors in the implementation of task-based teaching in primary schools. System, 31, 485-500.

Carless, D. (2007). The suitability of task-based approaches for secondary schools: Perspectives from Hong Kong. System, 35, 595-608.

Carless, K. (2013). Innovation in language teaching and learning. In C. A. Chapelle (ed.), The Encyclopedia of Applied Linguistics (pp. 1-4). US: Blackwell Publishing Ltd.

Carlson, R. O. (1968). Summary and critique of educational diffusion research. In Research implications for educational diffusion: Major papers presented at the National Conference on Diffusion of Educational Ideas (pp. 4-23). East Lansing, Michigan: Michigan State University.

Chang, L. U. (2000). Communicative language teaching: Senior high-school English teachers' belief and practice. Master Thesis, Taiwan: Tamkang University.

Chang, M. (2010). EFL teachers' attitudes toward communicative language teaching in Taiwanese college. Asian EFL Journal, 53, 17-34

Chen, Q. (1995). Let the pendulum swing and swing better: More thoughts on language teaching methodology.

Proceedings of the $21^{\text {st }}$ Annual Symposium of Deseret Language and Linguistics Society, Provo, UT. https://ojs.lib.byu.edu/spc/index.php/DLLS/article/view/31306

Coskun, A. (2011). Investigation of the application of communicative language teaching in the English language classroom: A case study on teachers' attitudes in Turkey. Journal of Linguistics \& Language Teaching, 21,85 - 109.

Ellis, R. (1994). The study of second language acquisition. Oxford: Oxford University Press.

Fullan, M. (1993). Change forces. US: The Falmer Press.

Gor, K., \&Vatz, K. (2009). Less commonly taught languages: Issues in learning and teaching. In: M. H. Long \& C. Doughty (eds.), The handbook of language teaching (pp. 234-249). US: Wiley-Blackwell. 
Gorsuch, G. (2000). EFL educational policies and educational cultures: Influences on teachers' approval of communicative activities. TESOL Quarterly, 34, 675-710.

Hawkey, R. (2006). Teacher and learner perception of language learning activity. ELT Journal, 60, 242-252.

Hiep, P. H. (2007). Communicative language teaching; unity within diversity. ELT Journal, 61, 193-201.

Hui, L. (1997). New Bottles Old Wine: Communicative Language Teaching in China. English Teaching Forum, 35, $38-41$.

Karavas-Doukas, E. (1995). Teacher identified factors affecting the implementation of an EFL innovation in Greek public secondary schools. Language, Culture and Curriculum, 8, 53-68.

Karavas-Doukas, E. (1996). Using attitude scales to investigate teachers' attitude to the communicative approach. ELT Journal, 50, 187-198.

Korthagen, F. A. J. (2004). In search of the essence of a good teacher: Towards a more holistic approach in teacher education. Teaching and Teacher Education, 20, 77-97.

Kumaravadivelu, B. (2006). TESOL methods: Changing tracks, challenging trends. TESOL Quarterly, 40, 59-81

Liao, X. (2003).Chinese secondary school EFL teachers' attitudes towards communicative language teaching and their classroom practices. Doctoral Dissertation. New Zealand: University of Auckland.

Li, D. (1998). It's always more difficult than you plan and imagine: Teachers' perceived difficulties in introducing the communicative approach in South Korea. TESOL Quarterly, 32, 677-703.

Liu, G. (2005). The trend and challenge for teaching EFL at Taiwanese universities. Regional Language Centre Journal, 36, 211-221.

Mulat. L. (2003). Teachers' attitudes towards communicative language teaching and practical problems in its implementation. Unpublished Master Thesis. Ethiopia: Addis Ababa University

Nation, I. S. P., \& Macalister, J. (2010). Language curriculum design. UK: Routledge

Orafi, S. \& Borg, S. (2009). Intentions and realities in implementing communicative curriculum reform. System, 37, 243-253.

Ozsevik, Z. (2010). The use of communicative language teaching (CLT): Turkish EFL teachers' perceived difficulties in implementing CLT in Turkey. Master Thesis. US: University of Illinois.

Phillipson, R. (1992). Linguistic imperialism. Oxford: Oxford University Press.

Rahimi, M., \& Asadollahi, F. (2011). On the relationship between Iranian EFL teachers' classroom management orientations and teaching style. Procedia Social \& Behavioral Sciences, 31, 49-55.

Rahimi, M., \& Naderi, F. (2013). The role of EFL teachers' attitudes towards communicative approach in their teaching style. Paper presented in the first National Conference in Teaching English, Literature and Translation. Shiraz, Iran.

Rathore, M. (2012). Teaching of English through methodology: Problems \& prospects. India: Ignite (India) Publishing.

Razmjoo, S. A., \& Riazi, A. (2006). Do high schools or private institutes practice communicative language teaching? A case study of Shiraz teachers' in high schools and institutes. The Reading Matrix, 6, 340-363.

Richards, J. C., \& Schmidt. (2002). Dictionary of language teaching and applied linguistics ( $3^{\text {rd }}$ ed.). UK: Longman.

Richards, J. C., \& Rodgers, T. S. (1986). Approaches and methods in language teaching ( $2^{\text {nd }}$ ed). Cambridge: Cambridge University Press.

Richards, J. C., \& Rodgers, T. S. (2001). Approaches and methods in language teaching ( $3^{\text {rd }}$ ed). Cambridge: Cambridge University Press.

Richards, J. C. (2006). Communicative language teaching today. New York: Cambridge University Press.

Rogers, E. (2003). The Diffusion Of Innovations (5th ed.). New York, NY: Free Press.

Rusch, E., \& Perry, E., (1999).Resistance to change: an alternative story. International Journal of Educational Reform, $8,291$.

Sato, K., \& Kleinsasser, R. (1999). Communicative language teaching: Practical understandings. The Modern Language Journal, 83, 494-517.

Savignon, S. (1991). Communicative language teaching: State of the Art. TESOL Quarterly, 25, 261-277.

Savignon, S. J., \& Wang, C. (2003). Communicative language teaching in EFL context: Learner attitudes and perceptions. IRAL, 41, 223-249.

Surafel, Z., (2002). The effects of the new English language teaching methodology in the first cycle secondary schools. Educational Journal, 6, 70-86.

Tsai, T. H. (2007). Taiwanese educators' perspective on the implementation of the new English education policy. Doctoral Dissertation, US: Alliant International University. 
Appendix 1. Attitudes towards CLT Questionnaire (Karavas-Doukas, 1996).

\begin{tabular}{|c|c|c|c|c|c|}
\hline Items & $\begin{array}{c}\text { Strongly } \\
\text { Agree } \\
5\end{array}$ & $\begin{array}{c}\text { Agree } \\
4 \\
\end{array}$ & $\begin{array}{c}\text { Uncertain } \\
3 \\
\end{array}$ & $\begin{array}{c}\text { Disagree } \\
2 \\
\end{array}$ & $\begin{array}{c}\text { Strongly } \\
\text { Disagree } \\
1\end{array}$ \\
\hline \multicolumn{6}{|l|}{$\begin{array}{l}\text { 1. Grammatical correctness is the most important criterion by } \\
\text { which language performance should be judged. }\end{array}$} \\
\hline \multicolumn{6}{|l|}{$\begin{array}{l}\text { 2. Group work activities are essential in providing opportunities } \\
\text { for co-operative relationships to emerge and in promoting } \\
\text { genuine interaction among students. }\end{array}$} \\
\hline \multicolumn{6}{|l|}{$\begin{array}{l}\text { 3. Grammar should be taught only as a means to an end and not } \\
\text { as an end in itself. }\end{array}$} \\
\hline \multicolumn{6}{|l|}{$\begin{array}{l}\text { 4. Since the learner comes to the language classroom with little } \\
\text { or no knowledge of the language, he/she is in no position to } \\
\text { suggest what the content of the lesson should be or what } \\
\text { activities are useful for him/her. }\end{array}$} \\
\hline \multicolumn{6}{|l|}{$\begin{array}{l}\text { 5. Training learners to take responsibility for their own learning } \\
\text { is futile since learners are not used to such an approach. }\end{array}$} \\
\hline \multicolumn{6}{|l|}{$\begin{array}{l}\text { 6. For students to become effective communicators in the } \\
\text { foreign language, the teacher's feedback must be focused on the } \\
\text { appropriateness and not the linguistic form of the students' } \\
\text { response. }\end{array}$} \\
\hline \multicolumn{6}{|l|}{$\begin{array}{l}\text { 7. The teacher as "authority" and "instructor" is no longer } \\
\text { adequate to describe the teacher's role in the language } \\
\text { classroom. }\end{array}$} \\
\hline \multicolumn{6}{|l|}{$\begin{array}{l}\text { 8. The learner-centered approach to language teaching } \\
\text { encourages responsibility and self-discipline and allows each } \\
\text { student to develop his/her full potential. }\end{array}$} \\
\hline \multicolumn{6}{|l|}{$\begin{array}{l}\text { 9. Group work allows students to explore problems for } \\
\text { themselves and thus have some measure of control over their } \\
\text { own learning. It is therefore an invaluable means of organizing } \\
\text { classroom experiences. }\end{array}$} \\
\hline \multicolumn{6}{|l|}{$\begin{array}{l}\text { 10. The teacher should correct all the grammatical errors } \\
\text { students make. If errors are ignored, this will result in imperfect } \\
\text { learning. }\end{array}$} \\
\hline \multicolumn{6}{|l|}{$\begin{array}{l}\text { 11. It is impossible in a large class of students to organize your } \\
\text { teaching so as to suit the needs of all. }\end{array}$} \\
\hline \multicolumn{6}{|l|}{$\begin{array}{l}\text { 12. Knowledge of the rules of a language does not guarantee } \\
\text { ability to use the language. }\end{array}$} \\
\hline \multicolumn{6}{|l|}{$\begin{array}{l}\text { 13. Group work activities take too long to organize and waste a } \\
\text { lot of valuable teaching time. }\end{array}$} \\
\hline \multicolumn{6}{|l|}{$\begin{array}{l}\text { 14. Since errors are a normal part of learning, much correction is } \\
\text { wasteful of time. }\end{array}$} \\
\hline \multicolumn{6}{|l|}{$\begin{array}{l}\text { 15. The Communicative approach to language teaching } \\
\text { produces fluent but inaccurate learners. }\end{array}$} \\
\hline \multicolumn{6}{|l|}{$\begin{array}{l}\text { 16. The teacher as transmitter of knowledge is only one of the } \\
\text { many different roles he/she must perform during the course of a } \\
\text { lesson. }\end{array}$} \\
\hline \multicolumn{6}{|l|}{$\begin{array}{l}\text { 17. By mastering the rules of grammar, students become fully } \\
\text { capable of communicating with a native speaker. }\end{array}$} \\
\hline \multicolumn{6}{|l|}{$\begin{array}{l}\text { 18. For most students language is acquired most effectively } \\
\text { when it is used as a vehicle for doing something else and not } \\
\text { when it is studied in a direct or explicit way. }\end{array}$} \\
\hline \multicolumn{6}{|l|}{$\begin{array}{l}\text { 19. The role of the teacher in the language classroom is to } \\
\text { impart knowledge through activities such as explanation, } \\
\text { writing, and example. }\end{array}$} \\
\hline \multicolumn{6}{|l|}{$\begin{array}{l}\text { 20. Tasks and activities should be negotiated and adapted to suit } \\
\text { the students' needs rather than imposed on them. }\end{array}$} \\
\hline $\begin{array}{l}\text { 21. Students do their best when taught as a whole class by the } \\
\text { teacher. Small group work may occasionally be useful to vary } \\
\text { the routine, but it can never replace sound formal instruction by } \\
\text { a competent teacher. }\end{array}$ & & & & & \\
\hline
\end{tabular}


22. Group work activities have little use since it is very difficult for the teacher to monitor the students' performance and prevent them from using their mother tongue.

23. Direct instruction in the rules and terminology of grammar is essential if students are to learn to communicate effectively.

24. A textbook alone is not able to cater to all the needs and interests of the students. The teacher must supplement the textbook with other materials and tasks so as to satisfy the widely differing needs of the students.

Appendix 2. Perceived Difficulties of CLT Implementation Questionnaire (Ozsevik, 2010).

\begin{tabular}{|c|c|c|c|c|}
\hline Items & $\begin{array}{c}\text { Not a } \\
\text { challenge } \\
1 \\
\end{array}$ & $\begin{array}{c}\text { Mild } \\
\text { challenge } \\
2 \\
\end{array}$ & $\begin{array}{c}\text { Challenge } \\
3 \\
\end{array}$ & $\begin{array}{c}\text { Major } \\
\text { challenge } \\
4 \\
\end{array}$ \\
\hline 1. Teachers' proficiency in spoken English is not sufficient. & & & & \\
\hline $\begin{array}{l}\text { 2. Teachers lack the knowledge about the appropriate use of language in } \\
\text { context. }\end{array}$ & & & & \\
\hline $\begin{array}{l}\text { 3. Teachers lack the knowledge about the target language (English) } \\
\text { culture. }\end{array}$ & & & & \\
\hline 4. There are few opportunities for teachers to get CLT training. & & & & \\
\hline $\begin{array}{l}\text { 5. Teachers have little time to develop materials for communicative } \\
\text { classes. }\end{array}$ & & & & \\
\hline 6. Teachers have misconceptions about CLT. & & & & \\
\hline 7. Students have low-level English proficiency. & & & & \\
\hline 8. Students have a passive style of learning. & & & & \\
\hline 9. Students resist participating in communicative class activities. & & & & \\
\hline 10. Students lack motivation for developing communicative competence. & & & & \\
\hline 11. There is a lack of enough support from administration. & & & & \\
\hline $\begin{array}{l}\text { 12. Teachers lack authentic materials such as newspapers, magazines, } \\
\text { movies etc. }\end{array}$ & & & & \\
\hline $\begin{array}{l}\text { 13. Traditional view on teachers' and learners' role is not compatible with } \\
\text { CLT. }\end{array}$ & & & & \\
\hline 14. Classes are too large for the effective use of CLT. & & & & \\
\hline $\begin{array}{l}\text { 15. Grammar-based examinations have a negative impact on the use of } \\
\text { CLT. }\end{array}$ & & & & \\
\hline $\begin{array}{l}\text { 16. There is a lack of effective and efficient instruments to assess } \\
\text { communicative competence. }\end{array}$ & & & & \\
\hline $\begin{array}{l}\text { 17. CLT doesn't take into account the differences between EFL and ESL } \\
\text { teaching contexts. }\end{array}$ & & & & \\
\hline $\begin{array}{l}\text { 18. Western educational assumptions are not suitable within Asian } \\
\text { contexts. }\end{array}$ & & & & \\
\hline
\end{tabular}

